\title{
Modeling the Internalization of External Costs of Transport
}

\author{
Margaret M. O’Mahony, Kieran J. Kirwan, and Sean McGrath \\ Published in Transportation Research Record (1997), 1576, 93-98.
}

\begin{abstract}
Increases in traffic congestion and pollution levels in urban areas in Europe have resulted in the need to develop reliable and transferable methods of assessing the environmental and social effects of transport pricing and other regulatory policies. To achieve this, it is necessary to quantify the marginal social costs of transport as a function of travel demand and then to obtain the optimum marginal social cost of maximization of utility subject to budget constraints. The work conducted by Trinity College, Dublin, on a project (TRENEN) funded by the European Union JOULE II Non-Nuclear Energy program is described. The project involved the development and calibration of an optimization model, the TRENEN model, based on welfare economics to address fundamental issues relating to the external costs of transport. The determination of the optimum function type was used to represent the transport-demand-delay relationship (which was obtained using an existing four stage network model) for input to the TRENEN model is described. The TRENEN model is quite different from network modelling in that it is fundamentally macro-level in its approach and works in an economic framework rather than at a traffic network level. Also discussed is a calibration of the TRENEN model for Dublin, the capital city of Ireland. Dublin currently experiences high levels of traffic congestion, particularly in the morning peak period, resulting from a heavy demand for car travel and poor level of service associated with public transport. The possibility of using the TRENEN model, which addresses the issue of 'social equilibrium' at a macro-level, in conjunction with the more traditional 'network equilibrium' approach used by traditional four-stage microsimulation modelling techniques is discussed.
\end{abstract}

\section{Introduction}

Increasing concern over traffic congestion and traffic-related pollution levels has resulted in the need to estimate their costs to the environment and to other transport users and nonusers. In Europe, car drivers pay the private cost of travel such as the capital cost of their car, fuel cost, marginal depreciation cost, insurance, and car tax. However, car drivers generally do not pay for the marginal social cost of their travel such as delay imposed on others, engine emissions to the environment, noise and higher accident risks. The higher accident costs refer to the marginal external accident costs, which consists of the part of accident cost not included in the insurance premium. It also includes the costs for all other road users due to the increased risk per $\mathrm{km}(0.6 \mathrm{mi})$ of travel. In the valuation of accident costs, account is taken of the willingness of the victim to avoid an accident, the willingness of family and friends to avoid it and the direct economic costs of an accident (e.g. work output loss and ambulance costs).

To evaluate the external costs of transport, the problem must be case in a framework that allows flexibility in the instruments that might be used to internalize these costs. In general terms the internalization of a cost, such as the external cost of transport, implies some means of taxation of the customer. Compared with other commodities, transport allows for more flexible means of internalization of costs (in addition to taxation) by the inclusion of regulatory policies, such as parking restraints, the imposition of cleaner car technology on car manufacturers, and perhaps subsidization of cleaner modes of transport. To analyze such issues on the basis of traffic demand and supply, a 
framework is needed under which all methods of internalization of external costs can be considered. Such a framework is provided by the TRENEN model (1), an economics-based model which allows for the examination of the optimal combination of pricing and regulatory policies. The model was developed under the European Union JOULE II Non-Nuclear Energy Program by Ochelen and Proost (1).

The TRENEN model is built on the work of Glaister and Lewis (2), who developed a model to describe the variation in demand for three competitive modes: private car, bus and rail. The model was used to derive optimal bus and rail prices with the assumption that car prices could not be varied. The TRENEN model considers a greater number of transport modes and includes a fuller consideration of the social costs of these modes. The social costs considered by the model include traffic congestion, pollution, noise and accident costs. The regulating policies to be assessed include transport pricing, vehicle standards, and traffic management measures.

The paper describes two parts of the research project. The first is a presentation of the development of a traffic flow-delay relationship for input to the TRENEN model and the second is the calibration of the TRENEN model for Dublin.

\section{Congestion Function for Input to the TRENEN Model}

The TRENEN model works at a macro-level and is unlike traditional four-stage network models in that it does not simulate at street or intersection conditions. It models at city level and includes a hierarchical structure starting at the top level, where a user decides to purchase 'transport' or 'other goods'. If the user selects transport, there is a choice between private and public transport, and each of these choices breaks down further to allow for more detail, such as in the case of private transport the size of the car, the fuel type, whether the car is used for carpooling, and so forth. Demand and supply data for calibration of the TRENEN model for any particular city can be obtained from a variety of national/local sources ranging from local authorities to motor organisations. A nested structure of elasticities of substitution represents the ease with which a consumer will substitute one mode of travel for another.

To measure the marginal social cost of traffic congestion, the model requires a flow-delay relationship. Such a relationship is normally associated with traffic at street level, and the fact that the model works at a city level makes it necessary to develop an aggregate function that in some way represents traffic delay in the city as a function of demand.

A network model of Dublin (of the traditional four-stage type), including modules for trip generation, trip distribution, modal split and trip assignment) using the SATURN suite (3) simulation and assignment model (calibrated for Dublin during the Dublin Transportation Initiative (4)) was used to examine the problem of developing a representative traffic flow-delay relationship for input to the TRENEN model. The network model covers two time periods representing the morning peak period and the off-peak period, and the network is modelled at two levels, buffer and simulation. For the buffer links, which for the most part are used to represent the outer suburbs of the city, a simplified representation of delay as a function of the flow on the link itself is used (i.e. the flows on other links are not taken into account). In the case of the simulation network, which covers the central business district (CBD), the calculation is more detailed and more representative of the real situation in that delays at junctions are calculated as a function of traffic control characteristics and of flows on all approaches. 
The simulation area representing the CBD of Dublin has 776 junctions, of which 443 are priority junctions, 320 are signalized junctions and the remaining 13 are roundabouts. In total, this represents 2,272 node-to-node links and 4,764 simulated turns. The buffer network consists of 252 nodes and 381 links. Traffic is loaded onto the network by means of a trip table consisting of 367 zones. The trip table was determined by roadside interviews and table estimation techniques using traffic counts conducted by the local authorities during the Dublin Transportation Initiative (4).

In a study undertaken for a Belgian urban area by De Borger et al (5) during the early stages of the TRENEN model development, the marginal external cost of congestion was calculated by making three basic assumptions about the relationship between average network speed and traffic levels. From observations of traffic in Belgian urban areas, it was assumed that the average network speeds were 50 $\mathrm{kph}$ (31 mph) for free-flow conditions, falling to $30 \mathrm{kph}(18.6 \mathrm{mph})$ at 5.6 million pcu-km $(3,479,840 \mathrm{pcu}-$ $\mathrm{mi})$ and to $10 \mathrm{kph}(6.2 \mathrm{mph})$ at traffic levels of 7 million pcu-km (4,349,800 pcu-mi). On the basis of this information the following parabolic relationship was found by De Borger et al (5) by using a functionfitting technique to the three data points (traffic levels/delay) mentioned above.

$$
d=6133949+138926.12 s-5232.102 s^{2}
$$

Where $d$ is the total vehicle equivalent kms travelled in the city and $s$ is the average speed (kph) at traffic level d.

Taking the inverse of Equation 1 to make the relationship better suited for input to the TRENEN model, the average time taken to travel $1 \mathrm{~km}, \mathrm{t}$, as a function of the vehicle equivalent kms travelled can be obtained by

$$
t=\frac{1}{s}=\frac{-10464.204}{\left\{-138926.12+\left\lfloor 138926.12^{2}+(20928.408)(6133949)-(20928.408) d\right\rfloor^{0.5}\right\}}
$$

This means of representation is useful in that only three levels of demand are needed. However, on closer examination of the form of function used, it can be seen that there are some difficulties in the use of this type of function for the purpose of representing traffic delay where at traffic levels greater than 7 million pcu-km (4,349,800 pcu-mi) the function reaches a discontinuity. Such discontinuities cause difficulties during optimization of the TRENEN model. Possible improvements to this relationship were investigated, although compatibility with the TRENEN model was ensured by maintaining units similar to those of De Borger et al (5) (i.e. pcu-km rather than trips). [The unit to represent demand in standard network models is trips whereas in the TRENEN model transport demand is represented in pcu-km].

To improve on the function form of the flow-delay relationship developed by De Borger et al [5], a trip table factorization method was used for development of the relationships for the peak and off-peak periods, where the trip table in both case was factored from 0.5 to 1.0 in steps of 0.1 . The table factored by a factor of 1 represents conditions in Dublin in 1991 (based year case). Multiplying the table by 0.5 , e.g., reduces the number of trips made on the network by $50 \%$ whereas multiplying the table by 1.5 increases the number of trips by 505 . The same trip table was used as the base table for each factorization. However, each new table formed after a particular factorization was loaded onto the 
network to obtain the optimum trip assignment at that level of demand. From the results of the trip assignment the total travel distance in million pcu-km was extracted. This measure of travel demand was then plotted against time taken to travel $1 \mathrm{~km}$ at the traffic level represented by each table. The data for peak and off-peak periods are shown in Figure 1 . Since the travel distance calculated is for $1 \mathrm{hr}$ in the case of the peak and off-peak periods, the travel distance per hour could be considered as a measure of flow.

The relationships in Figure 1 appear similar for the most part. Some divergence at higher traffic levels can be noticed, although when this divergence was tested statistically by means of estimation of variance it was found not to be significant. The explanation for the divergence is that in the peak period traffic is generally concentrated on radial routes into the city and congestion occurs mainly on these links in the model, whereas during the off-peak period traffic is more widely distributed because trip purpose tends to be more varied, and so the cumulative delay on the network is not as high as in peak conditions.

A quadratic function of the type used by De Borger et al (5) was found not to be a good fit for the Dublin data sets (obtained from the factorization method described above) because beyond a certain traffic level the function reaches a discontinuity. It was considered that this discontinuity might cause difficulties in the optimisation procedures of the TRENEN model, so various mathematical functions were investigated (using curve fitting techniques) to describe the relationship better. The best was exponential by nature and of the following form (Equations 3 and 4 are for peak and off-peak respectively):

$$
\begin{aligned}
& t=1.633+0.0263 e^{2.486 d} \\
& t=1.523+0.0574 e^{1.833 d}
\end{aligned}
$$

This form was chosen because its function type was the function that best described the relationship between flow and delay data obtained from the factorization method mentioned earlier.

\section{Calibration of the TRENEN model for Dublin}

The TRENEN model (1) is a partial equilibrium model of the transport sector. This means that the effects on markets other than transport are not considered. The model simulation of market equilibrium is obtained via optimisation of the prices in a welfare function subject to constraints on the instruments to be used [e.g. the policy makers may decide not to allow any further taxation (above base year levels) of public transport]. The objective function used by the model is a weighted sum of consumer surpluses and the total producer surplus in the transport sector.

Before optimization can be performed by the model, a reference situation must be compiled, which represents base year conditions for the city under test with respect to transport demand, pricing and taxing regimes, and car technology. Using this reference situation as the starting point, the model was run in optimisation mode where the model is allowed to choose het best pricing and regulatory policies without any constraints. In effect, this optimum represents a very elaborate and effective tax and pricing regime, under which the actual marginal external cost of every passenger $\mathrm{km}$ in different traffic conditions is costed and charged so that all external costs are internalized. Other more realistic measures can be tested with the model (e.g. using instruments such as road tolls and cordon pricing), 
but for the purposes of this paper the results for the optimum case will be compared with that of the reference situation (base year).

\section{Input Data for Calibration of the TRENEN Model for Dublin}

The demand inputs for the TRENEN model are taken from the data compiled during a large transportation study conducted in Dublin called the Dublin Transportation Initiative (4). Some changes to the units in which demand is expressed were necessary because demand in the Dublin Transportation Initiative was expressed in trips for each mode, whereas in the TRENEN model demand is expressed as pcu-km. Within the private transport category, demand was further classified to include trips per engine size, per fuel type of vehicle and so forth. (A summary of the private and public transport demands is presented later).

Other inputs required by the TRENEN model are the costs associated with each transport mode. In terms of private transport, the car owner's costs consist of vehicle acquisition costs, periodically recurring fixed costs such as motor tax, other operating costs such as fuel and maintenance costs and parking charges.

The annual acquisition cost of a private vehicle represents the annual saving that must be made by an individual to be able to buy the same car after 6 years allowing for an interest rate of $8.6 \%(6)$. The acquisition cost is calculated using the assumption that an average car in use in an urban area travels $15,000 \mathrm{~km}$ per year. A full breakdown of the Irish private car fleet by fuel type and engine size in Dublin was not available but the Society of the Irish Motor Industry (6) indicates that few diesel models on the market in Ireland have an engine size less than 1.5 litre, so this was the smallest diesel class on which data could be found. All other costs mentioned above (e.g. motor tax) were found using data from Irish motor associations and government departments.

The external costs of congestion are calculated by the model using a congestion function of the type mentioned earlier relating demand with delay. The external costs of air pollution are based on emission factors (for oxides of nitrogen (NOX), carbon dioxide $\left(\mathrm{CO}_{2}\right)$, and volatile organic compounds (VOCs) for various types of vehicles and estimations of the social costs of these as presented by Mayeres (7). The values used are presented in Table 1.

The marginal external costs of accidents used in the case of Dublin are similar to those used for Brussels in the case study by Ochelen and Proost (1). The values of time as presented in Table 2 are the same as those calculated from stated preference work conducted during the Dublin Transportation Initiative (4). The value of time of car travel was taken as $3.87 \mathrm{ECU} / \mathrm{hr}(\$ 5.13 / \mathrm{hr})$ in the peak period (see Table 2$)$ and $4.71 \mathrm{ECU} / \mathrm{hr}(\$ 6.12 / \mathrm{hr})$ in the off-peak period. The higher costing in the off-peak period is based on the assumption that trips made during office hours are costed higher than trips made outside office hours. Travel in the peak period corresponds to the latter.

The price elasticities that the TRENEN model uses are presented in Table 3, where they are compared with the elasticities used in the model of Brussels (1). The elasticities in both cases are computed from transport data and stated preference tests on transport users in both cities. 
From Table 3, it can be seen that public transport demand is more elastic than private transport demand, particularly during off-peak periods. As one would also expect, transport demand in the offpeak period is more elastic than that in the peak period in the case of both public and private transport.

TABLE 1. Pollutant emissions factors and social costs (7)

\begin{tabular}{|l|l|l|l|}
\hline Type of vehicle & $\begin{array}{l}\text { NOX (grams per } \\
\text { veh.km) }\end{array}$ & $\begin{array}{l}\text { CO2 (grams per } \\
\text { veh.km) }\end{array}$ & $\begin{array}{l}\text { VOC (grams per } \\
\text { veh.km) }\end{array}$ \\
\hline $\begin{array}{l}\text { Gasoline vehicle } \\
\text { without catalytic } \\
\text { convertor }\end{array}$ & 0.75 & 181.44 & 3.5 \\
\hline $\begin{array}{l}\text { Gasoline vehicle with } \\
\text { catalytic convertor }\end{array}$ & 0.1 & 192.78 & 0.4 \\
\hline Diesel: turbo-diesel & 1 & 163.8 & 0.5 \\
\hline Bus & 16.2 & 1008.0 & 5.3 \\
\hline $\begin{array}{l}\text { Cost of emissions (ECU } \\
\text { per gram) }\end{array}$ & 0.002 & 0.00018 & 0.0045 \\
\hline
\end{tabular}

Note: $1 \mathrm{ECU}=\$ 1.3$ and 1 gram $=0.035$ ounce 
TABLI: 2 Summary of lopats to TRENEN Modet (क)

\begin{tabular}{|c|c|c|}
\hline Faraimeter & Peal Friad & Onf Peak Periad \\
\hline Velot of Thine & (ECt pertas) & (ECU per Bawn) \\
\hline Pdvale Trmsport. & 3.87 & $4 \pi$ \\
\hline Putis Tresspon & 1.52 & $4 \pi$ \\
\hline Nan-msobrised & 1.52 & $4 \pi$ \\
\hline Occopentog Ruter & (gervess per velible) & (persies per wable) \\
\hline Poalod Pivaie Vetich & 2 as & 2.45 \\
\hline Bus & 36.6 & 100 \\
\hline 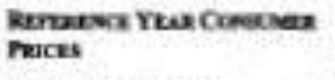 & 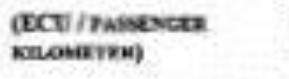 & 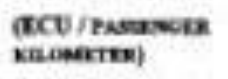 \\
\hline \multicolumn{3}{|l|}{ Privale Trasapent } \\
\hline 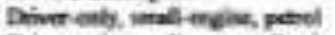 & 0.396 & 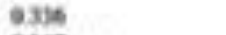 \\
\hline 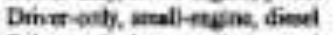 & 0.367 & 0367 \\
\hline Driver-enly, large-ergine, setrol & 0.436 & Q.96 \\
\hline 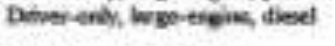 & 0.012 & 6,02 \\
\hline 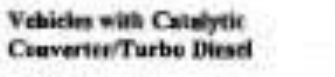 & $\begin{array}{l}\text { (as sbeve plus ast } \mathrm{ECU} \\
\text { per kn) }\end{array}$ & \\
\hline Panled Vuaticles & (ns nhout divited by 244) & \\
\hline \multicolumn{3}{|l|}{ rubike Treaspent } \\
\hline Bus & Q.44! & 0.141 \\
\hline Bati & 0.053 & Q06) \\
\hline $\begin{array}{l}\text { JuFuence Yeah Rrsoupcr } \\
\text { Corts }\end{array}$ & 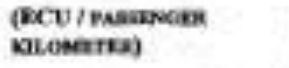 & 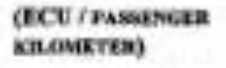 \\
\hline 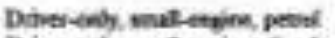 & 0205 & eans \\
\hline Dires-enty, snal-eneis, fiesd & 0.221 & 0.221 \\
\hline Dodve-enly, large-senine, petrol & 0.248 & 0.264 \\
\hline 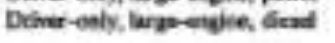 & a.2ss & 0253 \\
\hline $\begin{array}{l}\text { Vehickes with Cralytar } \\
\text { Converser/Turbe Diesel }\end{array}$ & 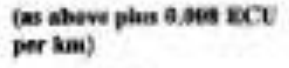 & \\
\hline Rutlest Viblales & (bs iteow dividal if 2 a) & \\
\hline \multicolumn{3}{|l|}{ Public Traatpart } \\
\hline Hua & 2.120 & 0.14 \\
\hline Ball & eloss & exes \\
\hline
\end{tabular}

Note. 1 BCD $=51.3,1 \mathrm{~km}=0.62$ mile

\section{TRENEN Results for Dublin}

Several policy scenarios were tested for Dublin using the TRENEN model but two have been selected for presentations in this paper; the reference situation representing the base year 1991 case and the optimum solution as calculated by the TRENEN model. The outputs from the reference case model run are sued as the reference point against which welfare changes of other policy scenarios may be measured. The changes in the transport market resulting from pricing and regulatory changes will be discussed with reference to three sets of outputs: prices, quantities of transport demanded, and welfare. The results from the reference case model runs are presented in Table 4, where the units used are expressed in quantity per average Dublin inhabitant.

\section{Prices in the Reference Case}

Since neither road pricing nor differential fares systems are currently used in Dublin, it is assumed in the reference situation that there is no variation in the consumer prices of transport with resepect to time of day or occupancy rate. For example, in the case of private transport the cost (money) of travel per vehicle $\mathrm{km}$ using any particular vehciel type is the same irrespective of time of day or number of 
occupants. The generalized price of car travel is higher in the off-peak period. This is because the offpeak period value of time assumed [(4.71 ECU/min $(\$ 6.123 / \mathrm{min})]$ is higher (travel during office hours is classified as more expensive) than that for the peak period [3.87 ECU/min $(\$ 5.03 / \mathrm{min})]$. The same is true of public transport but the difference is greater; the values of time assumed are $1.52 \mathrm{ECU} / \mathrm{min}$ $(\$ 1.625 / \mathrm{min})$ in the peak period and $4.71 \mathrm{ECU} / \mathrm{min}(\$ 6.12 / \mathrm{min})$ in the off-peak period. These values of tiem, as stated earlier, have been obtained using stated preference estimation techniques on transport user in Dublin (4). Another point to note in the reference case in Table 4 is that subsidization applies in the case of public transport to a value of $0.013 \mathrm{ECU}$ per passenger $\mathrm{km}$ ( $\$ 0.03$ per passenger mile).

TABLE 3 Price Rasticities for Transpert in Deblin $(S)$ and Brusseis

\begin{tabular}{|c|c|c|}
\hline Trabsent Mede / Rried & Debline Medel & Branule Madel \\
\hline Prvale transpot/peak peiod & -0.4 & -0.49 \\
\hline Privite transolon f of pelik period & -0.55 & Sot 6 \\
\hline Puhis tranyees / peak period & -5.5 & -6.45 \\
\hline Ratic traspon / ad-penk perat & 0.8 & 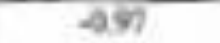 \\
\hline
\end{tabular}


TABLE 4 THENEN Reselts for Referese asd Optimum Cubs

\begin{tabular}{|c|c|c|}
\hline & Beferrece Cuse & Optienm Cave \\
\hline \multicolumn{3}{|l|}{ 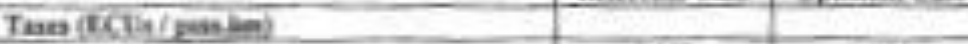 } \\
\hline$C=$ Fata & biy & 0.204 \\
\hline OAPAal: & 1.152 & o.18) \\
\hline Peal & 9921 & 0.092 \\
\hline Offitia & ad & 097 \\
\hline Pat & ald & QDi4 \\
\hline oft-pes: & 9013 & 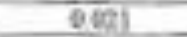 \\
\hline \multicolumn{3}{|l|}{ Money Price (ECD) pandan) } \\
\hline Crir Pak & a.311 & 6477 \\
\hline 0EPleh & ent & 0.394 \\
\hline hak & 0.141 & 5117 \\
\hline Ces-Pat & 8.141 & Q.19) \\
\hline Rak & ass & Q 200 \\
\hline Oefent & बats & ext1 \\
\hline \multicolumn{3}{|c|}{ 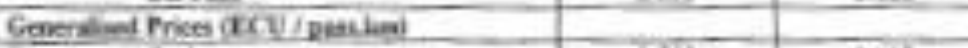 } \\
\hline Car Peak & 959 & 0.613 \\
\hline Off-hak & 0974 & 6519 \\
\hline And & 8207 & ozke \\
\hline OgFrer & QDI & 0.372 \\
\hline Rowk & 0104 & 0111 \\
\hline defrab & 910 & 0.245 \\
\hline \multicolumn{3}{|l|}{ 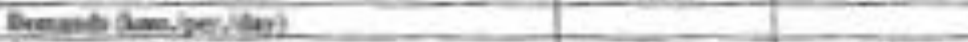 } \\
\hline Car Ponk & 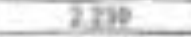 & $211 \%$ \\
\hline Oefrei & 912 & 9361 \\
\hline Pesk & $9+45$ & ext \\
\hline orfar & 111 & Lete \\
\hline Pak & b) 11 & 0316 \\
\hline Ore Perk & 974 & 0196 \\
\hline \multicolumn{3}{|l|}{ Sgerd din /hoser? } \\
\hline CF Mak & 310 & 243 \\
\hline Odifal & 1789 & 320 \\
\hline Fak & 2131 & 231 \\
\hline Qetpred & 2609 & 26.05 \\
\hline \multirow{2}{*}{ Re Pral } & $2 \times 6$ & 38 \\
\hline & 200 & 30.1 \\
\hline \multicolumn{3}{|l|}{$\begin{array}{l}\text { Weifare tedrabars } \\
\text { (ECU/proselday) }\end{array}$} \\
\hline Caxuner Sughtor & $4: 100$ & 04363 \\
\hline Car Tra Revene & 1.73 & 137 \\
\hline Robe Tiamgar Tax R resie & Dovi. & 018 \\
\hline Pahrien Cat & 9.169 & 2051 \\
\hline Astuer Co & (9) & Q393 \\
\hline Wifan & st: 131 & 6294 \\
\hline
\end{tabular}

Noke IECU $=51.3$ ad $1 \mathrm{kn}=0.62 \mathrm{mb}$

\section{Transport Demand in the Reference Case}

The transport demand values presented in Table 3 for the reference situation are those representing the 1991 base year case. Car travel accounts for a large proportion of total travel in the peak and off-peak oeriods, at $2.23 \mathrm{~km}(1.39 \mathrm{mi})$ and $9.322 \mathrm{~km}(5.79 \mathrm{mi})$ per person per day, respectively, particularly compared with rail, where the demands in the peak and off-peak periods are $0.381 \mathrm{~km}(0.24 \mathrm{mi})$ and $0.248 \mathrm{~km}(0.15 \mathrm{mi}$ ) per person per day, respectively. (Only a few corridors in Dublin are served by rail compared with the coverage available to private transport and bus). The changes in average speed relative to changing traffic levels for private transport in the peak and off-peak periods can be seen in Table 4, where the speed in the peak period is $28.49 \mathrm{~km} / \mathrm{hr}(17.7 \mathrm{mph})$ and in the off-peak period is 
$32.09 \mathrm{kph}(19.9 \mathrm{mph})$. Speeds for buses are slower, at $23.17 \mathrm{kph}(14.4 \mathrm{mph})$ in the peak period and $26.09 \mathrm{kph}(16.2 \mathrm{mph})$ in the off-peak period, than those of private transport due to required stops. Buses and private transport are assumed to be subjected to the same levels of congestion, because no facility is available as yet in the model to allow for bus lanes. It is assumed in the case of heavy goods vehicles that no further taxation will be applied and that heavy goods vehicle demand remains constant for both the reference situation and the optimum solution.

\section{Welfare in Reference Case}

Welfare is defined as the sum of producer surplus, consumer surplus, and tax revenues minus the external pollution and accident costs. The demands and prices presented in Table 4 are the values obtained when the objective function is maximized. The objective function contains three terms. The first measures utility as a function of generalized prices, income, profits and transferred tax revenue. The second term measures the extra shadow value of public funds, and the third value measures the total environmental damage in income equivalents. Details of the mathematics of the model are presented by Ochelen and Proost (1).

All welfare components are expressed in ECU per person per day ( $\$$ per person per day) (i.e. per average Dublin inhabitant) and can be seen in Table 4 to be 62.884 ECU (\$81.75) per person per day, consisting of a consumer surplus component [1.345 ECU (\$1.75) equal to the tax revenue multiplied by the scalar cost of public funds] minus the external costs of pollution [0.165 ECU $(\$ 0.215)]$ and accidents [0.396 ECU $(\$ 0.52)]$.

Another factor to consider when examining welfare is that the welfare gain can be obtained through increases in private and public transport revenue because one of the assumptions of the model is that the tax revenue generated from the transport sector by government is distributed to consumers in other ways. The revenue gains are always weighted by a constant scalar cost of public funds, which is used to represent the efficiency of collecting revenue in the transport market compared with other means of tax revenue generation. The scalar cost of public funds used in this case was 0.05 [e.g. tax revenue as presented for the reference case in Table 4, $1.28+0.001 \mathrm{ECU}$ per person per day is multiplied by 1.05 to give 1.345 ECU $(\$ 1.75)$ value as presented above.

\section{Prices in the Optimum Case}

After the reference situation has been established, the model was run to allow optimization without constraint, which represents an ideal situation where all external costs are internalized. The practical application of such internalization would be difficult since in the theory the real-time marginal external cost of every km (mile) of travel would need to be accounted for. Given the difficulties in applying this, the optimum situation should be seen as the case of maximum benefit against which other more practical policies should be measured. The results of this 'optimum' model run are presented in Table 4.

The results indicate that in the case of car travel, taxation in the optimum case is higher in the peak period at $0.206 \mathrm{ECU}$ per passenger $\mathrm{km}(\$ 0.43$ per passenger mile) than in the off-peak period at 0.152 ECU per passenger $\mathrm{km}$ ( $\$ 0.32$ per passenger mile). Given the high marginal external costs of congestion in the peak period, this different is not unexpected in that one would expect higher levels of taxation to cover the higher congestion costs.

At a more detailed level, the following because apparent from the optimum run output: 
- Because of the imposition of clean car technology in the optimum case, the resource cost of gasoline cars increases compared with that of diesel vehicles since no clean technology is currently considered efficient for application to diesel vehicles.

- In the case of the optimum, taxation on public transport increases and subsidies in the reference case are replaced by taxes. This results of proposed increased taxation of public transport is driven by gains to be obtained in tax revenue generation. Similar results were obtained in the case of Brussels (1).

\section{Transport Demand in the Optimum Case}

The summary demands presented in Table 2 indicate that in the optimum case the demand for car travel in the peak period decreases from 2.23 to $2.106 \mathrm{~km}$ per person per day (1.39 to $1.31 \mathrm{mi}$ per person per day), whereas a slight increase in demand is observed in the off-peak period [i.e. 9.322 to $9.361 \mathrm{~km}$ per person per day (5.79 to $5.82 \mathrm{mi}$ per person per day )]. An increase in speed in the peak period can be noted [i.e. from $28.49 \mathrm{kph}(17.7 \mathrm{mph})$ in the reference situation to $29.3 \mathrm{kph}(18.2 \mathrm{kph})$ in the optimum case], resulting from the corresponding decrease in demand for private transport. However, in the off-peak period an increase in demand from $9.322 \mathrm{~km}(5.79 \mathrm{mi})$ per person to $9.361 \mathrm{~km}$ (5.82 $\mathrm{mi}$ ) per person does not have the same effect on speed. This can be expected because the network in the off-peak period has more available capacity to allow for increases in demand. Bus travel demand remains more or less the same in the peak period but falls from 1.831 to $1.469 \mathrm{~km}$ (1.14 to 0.91 mi) per person per day in the off-peak period as a result of large increases in taxation. The substantial increases in rail fares applied in the optimum case results in a decrease in demand for rail travel in both peak and off-peak periods.

\section{Welfare in the Optimum Case}

The welfare results for the optimum case are presented in Table 4. Welfare in the full optimum case is calculated at $62.943 \mathrm{ECU}(\$ 81.83)$ per person per day, consisting of a consumer surplus component [61.843 ECU (\$80.40)], a tax revenue component [1.545 ECU (\$2.00) that equals the tax revenue multiplied by the scalar factor cost of public funds], minus the external costs of pollution [0.051 ECU (\$0.07)] and accidents [0.393 ECU (\$0.51)]. Pollution and accident externalities decrease, causing an overall welfare increase from the reference situation of $0.059 \mathrm{ECU}(\$ 0.08)$ per person per day, which is equivalent to approximately $0.1 \%$ of the reference year welfare level. Although this is relatively small increase, it is brought about by relatively small changes in the transport market, which account for $10.9 \%$ of total expenditure.

\section{DISCUSSION OF RESULTS AND CONCLUSIONS}

The TRENEN model runs for Dublin generated interesting results that are worthy of further discussion and comment. The model results suggest generally that car travel should be priced at a higher level in the peak period because of the external costs generated by traffic congestion that such increase are not necessary in the off-peak period. In addition, the model suggests that taxation of small-engine and large-engine cars should be similar, a trend that is again driven by the high external costs associated with congestion. As expected, the use of clean car technology is rewarded by lower external costs. The fare increases for public transport in the optimum case are driven by the potential tax revenue generation from public transport. 
Further development and examination of sensitivities of the TRENEN model would be required to refine its workings better. However, in addressing the increasingly important issues relating to environmental issues in the transport sector, it will prove a useful tool in evaluation policies for the internalization of external costs. Reference has already been made to it in the recent EU GREEN Paper (9). Some work has been done to investigate the possibility of using the macro approach of the TRENEN model in conjunction with network models. Although there are some difficulties in harmonization of the different approaches, some progress was made in comparing the modal split outputs of both models in the case of Dublin, where similar modal splits were achieved. The combined use of both models would allow for the examination of the effects at street level of the optimal policies decided upon by the TRENEN model for any city to be tested.

\section{ACKNOWLEDGEMENT}

The authors of the paper wish to acknowledge the support of the European Union JOULE II Non-Nuclear Energy Program, which provided the funding for the project on which this paper reports.

\section{REFERENCES}

1. Ochelen, S. and S. Proost. TRENEN - Urban Model Documentation Prototype Version 2.2. Katholieke Universiteit Leuven, Belgium, 1996.

2. Glaister, S. and D. Lewis. An integrated fares policy for transport in London. Journal of Public Economics, Vol. 9. 1978, pp.341-355.

3. Simulation and Assignment of Traffic to Urban Road Networks (SATURN) Model. W.S. Atkins Consulting Ltd., United Kingdom, 1996.

4. Dublin Transportation Initiative Final Report. Department of the Environment, Dublin, Ireland, 1994.

5. De Borger, B., I. Mayeres, S. Proost and S. Wouters. Social cost pricing of urban passenger transport, Public Economics Research Paper 34, Katholieke Universiteit Leuven, Belgium, 2993.

6. Economics and Businss - Annual Report, Society of the Irish Motor Industry, 1994.

7. Mayeres, I. The marginal external costs of car use - with an application to Belgium. Tijdschrift voor Economie en Management, Vol. 38, No. 3, 1993.

8. Kirwan, K.J. Optimal Transport Pricing for Dublin, Master's thesis, Trinity College Dublin, Ireland

9. Towards fair and efficient pricing in transport. Policy options for internalizing the external costs of transport in the European Union. Green Paper, Commission of the European Community, 2996. 